\title{
SUSTAINABILITY OF UNDP PROJECTS IN EGYPT: A CASE STUDY IN SIWA OASIS (SIWA ENVIRONMENTAL AMELIORATION PROJECT)
}

\author{
Mazen Barakat \\ Rural Sociology, Faculty of Agric., Ain-shams University, Cairo, Egypt
}

\begin{abstract}
The main objective of this research paper was to evaluate the effect of one of the international projects in Egypt, in order to know the benefit of such projects and to discover the reasons of their success or failure several criteria from different point of views.

Siwa Environmental Amelioration Project (SEAP) was chosen as one of the famous projects in Siwa Oasis. It worked there for two phases for 6 years in order to set sustainable development in the oasis.

The results showed that a lot of local obstacles faced the project and didn't help SEAP in achieving its goals. Besides, the other local NGO partner (SCDEC) was not qualified enough to take over the projects after SEAP left.

Even with the success of organic agriculture production as an innovation, the problem of marketing killed already the idea, and small farmers couldn't cope with it, and it ended by cancelling the activity
\end{abstract}

Keywords: sustainable agriculture, innovation

\section{INTRODUCTION:}

According to the Egyptian definition, Siwa Oasis is considered to be the city and district of Siwa. It located in the western desert, $800 \mathrm{~km}$ from Cairo the capital, and $300 \mathrm{~km}$ from Matrouh city, the capital of the Governorate, which it is administratively, follows. Siwa was isolated for a very long time since there was no direct road to drive there.

Through all this period of time(800 years according to different studies) Siwan people were managing their land and ground water sources within ten tribes through their own special social contract and a special tribes council that arrange most of their life issues socially and economically.

Although Siwa is located in Matrouh governorate, but it would had taken 18 hours to reach it from Matrouh city and almost one day from Cairo.

In the early 80 s a road was structured by the petroleum companies in order to connect Siwa Oasis with Matrouh city governorate.By that time the road was the innovation that connected Siwa to the world and helped in delivering many medical and technical services. Since that time tourism started to be a basic source of income for Siwan community, this road even gave the chance for Siwan youth to join university education. 


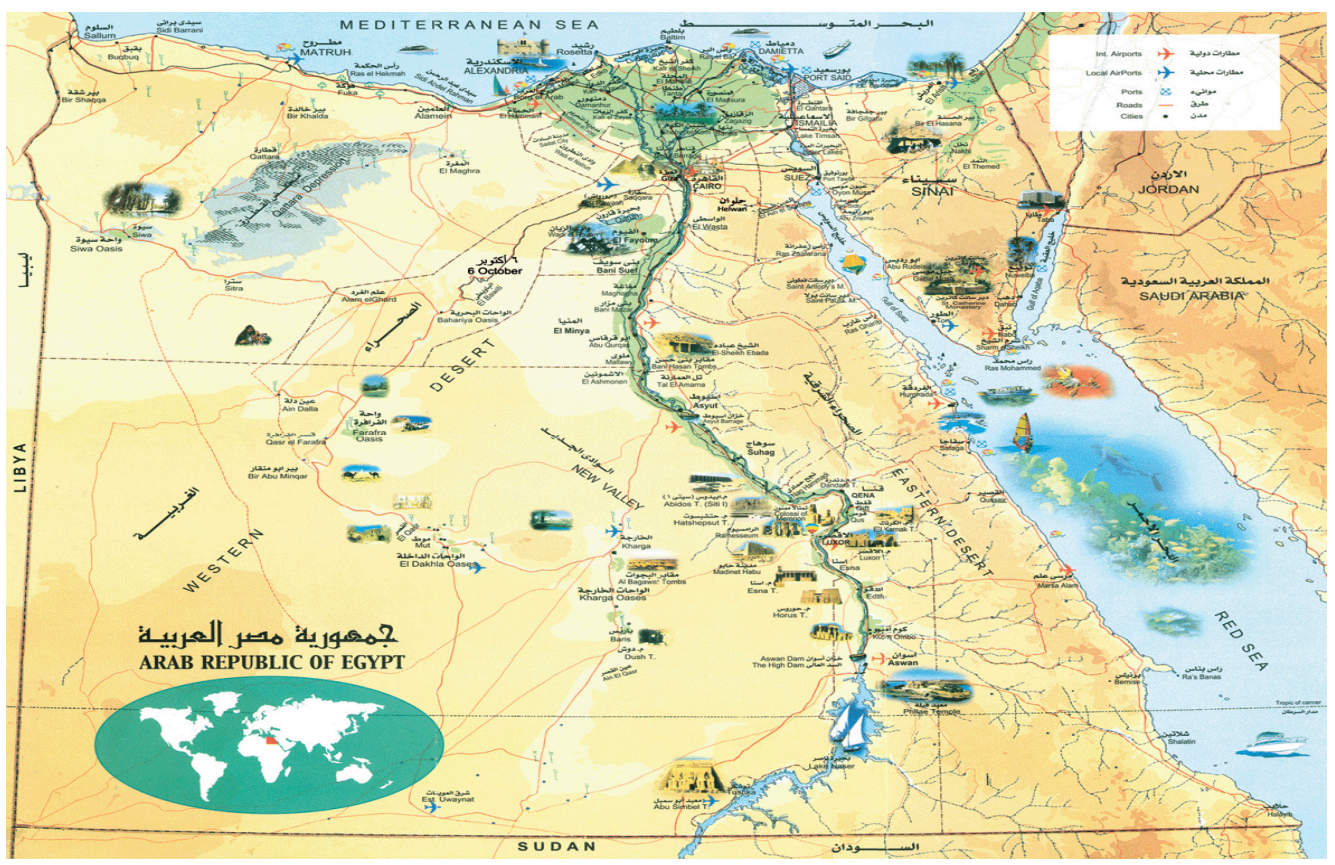

\section{Study problem:}

No doubt that many international organizations were interested to study and help to develop this isolated community in order to improve those people's life and help in developing their sustainable resources management, UNDP (United Nation Development Program) and EIECP (Egyptian Italian Environmental Cooperation Program) were the first international organizations that started projects aiming to develop the Siwan community through improving the quality of life, that's why the current study aimed to evaluate one of the famous projects out there SEAP and its impact and sustainability with its positive or negative impact on Siwan community.

\section{Study goals:}

1. Evaluation of SEAPin achieving its goals.

2. Evaluating the benefits of such projects for the Siwan community

\section{Background concepts:}

The following concepts had been guided the assessment and there search through of the fieldwork of the present study ;it must be indicated that, all the references of these concepts were the lectures 
given by IAMB staff in the advanced special course of sustainable agriculture "2010-2011"

- Sustainable agriculture:

It is the system of polices, institutions, and communities aiming to conserving natural resources and environment, to provide

1. Food security (food and fiber).

2. Poverty eradication.

3. Developing national and local communities.

4. Cultural heritage.

- Sustainable development

It is the development that meets the need of the present, without compromising the ability to future generations to meet their own needs (IAMBstaff lectures WCED-1987)

- NGO,s

It is a non-governmental agency operating outside the

Methodology:

commercial sector and work on one or more special issues

-A long field visit was prepared from 1-10/4 /2016

-Sample \& data Collection:

Personal interviews were done to the key persons and

informants. Group discussion technique took place with the farmers organic agricultural group -16 people, as well as secondary SEAP' data.

\section{Key informants:}

- Abdullah Aeed: used to be the project officer of SEAP.

- Anwar sarhan: the director of SCDEC (Siwa Community Development and Environment Conservation).

- Sheikh sayed: the head of the trips council and head of SCDEC.

\section{-Data presentation \& Analysis}

Some of SEAGA (Socio Economic and Gender Analysis) tools were used according to the field study and community special traditions:

- Ven diagram

- Pair-wise analysis

- A ven diagram was prepared with SEAP management unit in order to know the linkage betweendifferent actors involved in the project. The importance of each actor is represented by a circle sized according to its importance, while the level of overlapping between them shows the degree of contact.

-A pair wise analysis was done three times. One with each of:SEAP team, SCDEC management unit, and thirdly with the farmers as a way 
to identify the main problems faced and how each sees SEAP success or failure from their different point of view.

\section{Results:}

UNDP with the cooperation of EIECP started in 1998 applying SEAP first phase for three years. This project aimed at developing Siwan community through giving micro credits to each Sheikh of a tribe who was responsible to recycle the loans inside his own tribe among the farmers, but by the end of the project a big dilemma started to arise since most of the loans were not given back.

SEAP project discussed with the tribes the idea of establishing an association responsible for recycling those loans, as a way to solve the problem of not paying back the loans.

The association was established in 2001 by 31 members with a management council of 13 members representing the 10 tribes (one member from each tribe) and three villages (one member from each village). The council managementmembers' changes every six years.

In 2004 the second phase of SEAP was agreed with different perspectives between EIECP and MOIC (Ministry of international cooperation) under the supervision of UNDP

The project had three main goals

1. Turning Siwa into an international natural park.

2. Achieving sustainable agriculture development through

a. Achieving organic agriculture system

b. Improving local animal production

3. Using SDEC organization as a local partner to take over the activities after they will leave.

The following ven diagram in (fig 1) was used to show the linkage between different actors in SEAP, the area of the circles shows the degree of importance while the level of over lapping shows the degree of contact. 


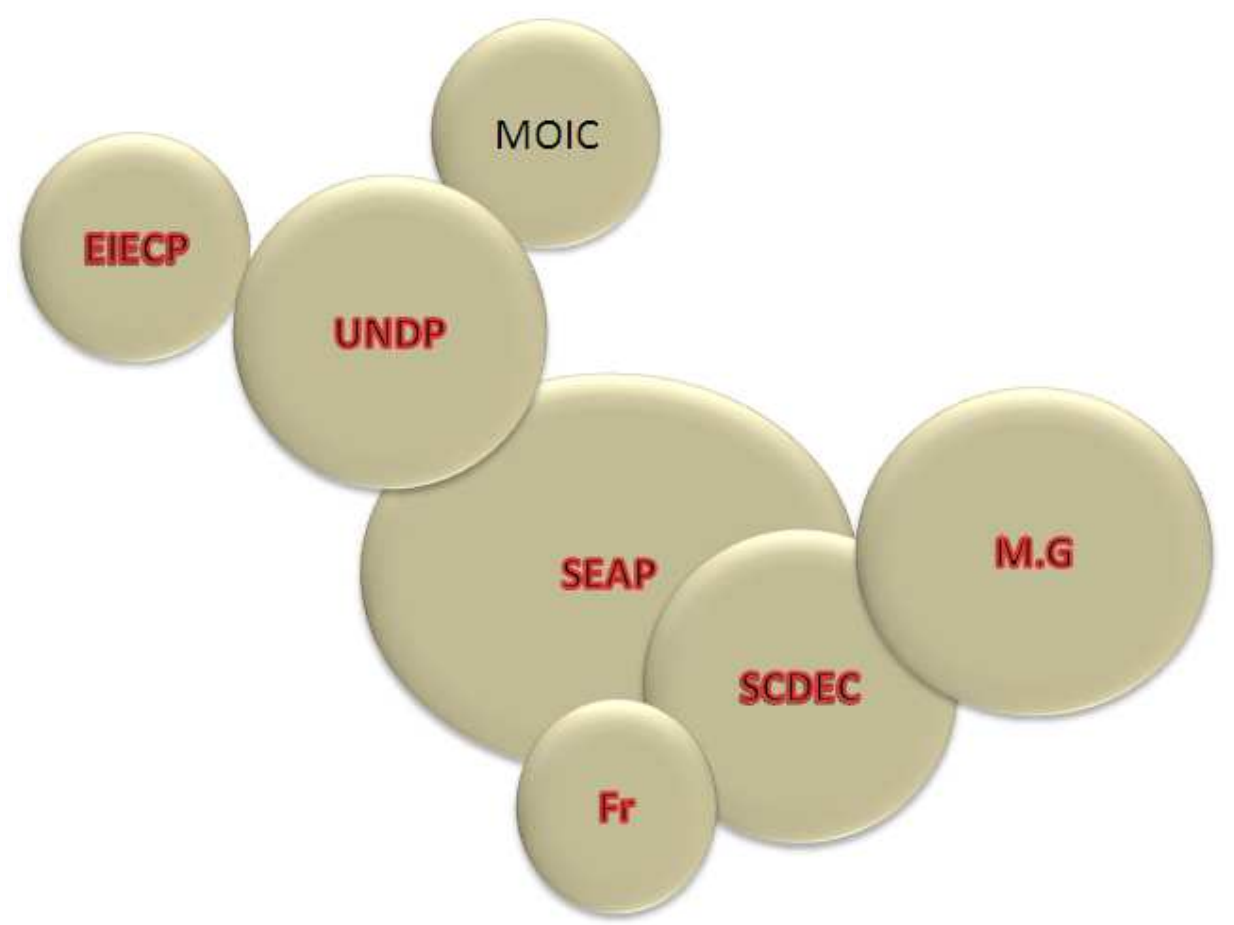

(fig 1) ven diagramshowing the linkage\& Thedegree of contact between actors in SEAP.

Key:

MOIC: Ministry of International Cooperation

EIECP: Egyptian Italian Environmental Cooperation Program

UNDP:United Nation Development Program

SEAP: Siwa Environmental Amelioration Project

SCDEC: Siwa Community Development and Environment Conservation

M.G : Matrouh governorate

Fr: Farmers

\section{Meeting and group discussion results:}

1. The international natural park was not applied because suddenly and with no reason the governor of matrouh decided to be an obstacle in front of SEAP goals, he negotiated for more than one year the possibility of cutting part of the project fund for achieving a medical natural ecology which was impossible because it was not mentioned in the agreement signed before.

That's illustrating why UNDP stopped negotiation and transferred the budget of that part to another place, leaving SEAP only with a small budget for the agriculture issues.

2. According to the agreement signed in 2003, SEAP was obliged to use consultants only from national research centers, SEAP 
Management suffered a lot because they were unqualified consultants and miss leaded them.

3. The project was left with a small fund to work on the second and third objectives only, according to the socio economic studies done by the specialist, SEAP management decided to start organic agriculture production by establishing a demonstration organic farm, 16 Fadden given to 16 youth fresh graduate Siwan, they were chosen carefully according to special application and within the tribes applied by SCDEC and supervised by SEAP.

Consultants taught them about organic agriculture steps and compost preparations, drip irrigation system was installed and all infrastructures were settled dawn by SEAP and given to farmers as a loan should be paid back to SCDEC to recycle it and transfer the new innovation to other farmers

The final highly coast product could not be sold in local markets or even in organic markets whether in Alexandria or Cairo due to the large distance and the small production for the16 feddan.

Unfortunately farms removed the drip irrigation system and went back to surface irrigation system and now they are cultivating natural products for local markets and loans were never paid back.

4. The animal production specialist after two weeks of studying the Siwan conditions delivered special cows to the association in order to deliver to small farmers as a loan but the cows died directly after arriving due to high temperature and ticks. The contract with the research center for delivering the animals was canceled, SEAP management decide to build an animal demonstration farm for goats and sheep to produce animals given as loans for small farmers and women and to be managed by the association even after SEAP will leave.

After the project was finished the association refused to take over the demonstration farm and sadly it was closed and loans were never paid back

5. Pairwise ranking matrix was used to show the most important problems. 


\section{Matrix (fig 2) represent SEAP management point of view and was prepared through personal interviews.}

\begin{tabular}{|c|c|c|c|c|c|}
\hline \multicolumn{6}{|c|}{ Pair wise ranking matrix according to SEAP. .Janaggement } \\
\hline proplems & Matrouh Governer & unerperience specialist & unqualified association members & cutting fund & farmers adopting nerr inrations \\
\hline Iatroulh Govermer' & & Matroulh Govetile" & Matroul Govelner & Matrould Goveremer & Mattoulh Goventete" \\
\hline unexperience specialist & & & unerpententece specaidist & therpentence specialist & wulespentences specialist \\
\hline unqualified association members & & & & unculalified association members & ungualified association members \\
\hline cultiting find & & & & & couting fiund \\
\hline \multicolumn{6}{|l|}{ farmers adopting new inrations } \\
\hline & & problem & time preferered & rank & \\
\hline & & Matroulh Governer & 4 & 1 & \\
\hline & & unerperience specialist & 3 & 2 & \\
\hline & & unqualififed association members & 2 & 3 & \\
\hline & & cutting fund & 1 & 4 & \\
\hline & & farmers adopting nerr inrations & 0 & 5 & \\
\hline
\end{tabular}

It was clear from SEAP management that matrouh governor was the strongest obstacle against achieving the project goals, and on the other hand the project suffered to use certain specialists from certain place and didn't had the flexibility to choose.

\section{6- Matrix (fig 3) represent SCDEC management point of view and was prepared through personal interviews}

Pair rise ranking mattix according to SCDEC .Hanagement

\begin{tabular}{|c|c|c|c|c|c|}
\hline proplems & goalls of SEAP was not cleal & shoottage of triained people & shoitage of funding & farmers connections & tribes council \\
\hline goalls of SEAP was not clear' & & goolls of SEAP wras not cleat" & goolls of SEAP wass 1ot clear" & goalls of SEAP wras not claat & goalls of SEAP was not clear \\
\hline shortage of thained people & & & shoot tage of trained people & shootage of trained people & slootage of tained people \\
\hline shortage of funding & & & & shottage of tunding & shottage of funding \\
\hline farmers connections & & & & & fatmerts contilections \\
\hline \multicolumn{6}{|l|}{ tibes council } \\
\hline & & problem & time prefererred & rankk & \\
\hline & & goalls of SEAP was not cleal' & 4 & 1 & \\
\hline & & shortage of trained people & 3 & 2 & \\
\hline & & shortage of funding & 2 & 3 & \\
\hline & & farmers connections & 1 & 4 & \\
\hline & & tribes council & 0 & 5 & \\
\hline
\end{tabular}

SCDEC is local NGO created in 2001 with the help of SEAP first phase, the association is considered to be the formal way of the tribes' council to be presented and take over responsibilities to manage the Siwan resources and to support supervise the projects applied in siwa 
since that the agreement of the association management council mean the agreement of the tribes

SCDEC under the tribes control failed to take over and manage the sustainable agriculture projects, we have to mention that SCDEC reputation among other projects started to fail dawn since that a lot of projects now are not interested in SCDEC to be their local NGO partner, and of course there is no other NGO in siwa

\section{7- Ranking matrix (fig 4) represents the farmers' point of view}

\begin{tabular}{|c|c|c|c|c|c|}
\hline \multicolumn{6}{|c|}{ Ranking mathis represesents the fammers' point of rierr } \\
\hline proplems & malketing proplems & liggh costs of infriastivucture & bal communication nith SCDEC & organic certification problems & mater problems \\
\hline marketing proplems & & 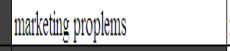 & maledeting yroplems & mantetefing proplens & maxtering propolems \\
\hline ligh costs of inflifrasturcture & & & high costs of iffrastuchutue & high costs of infinastronture & Ligh costs ofifingsinucture \\
\hline bad communication rith SCDEC & & & & bad communimication rith SCDEC & bad communumedion witit SCDEC \\
\hline ovganic certification problems & & & & & organic certification problems \\
\hline \multicolumn{6}{|l|}{ water problems } \\
\hline & & problem & time preferered & rank & \\
\hline & & marketiug proplems & 4 & 1 & \\
\hline & & high costs of infriastructurue & 3 & 2 & \\
\hline & & bad communication with SCDEC & 2 & 3 & \\
\hline & & organic certification problems & 1 & 4 & \\
\hline & & Trater problems & 0 & 5 & \\
\hline
\end{tabular}

It was clear from the group discussions with the farmers group that they faced a lot of problems in marketing specially with th high infrastructure costs which should be given back to SCDEC as a loan in order to recycle the experience and transfer the innovation to other farmers.

Since the final products was highly costly with no suitable market and no good price, they failed to continue after SEAP ended and turned to traditional agriculture products, even when they tried to build another association for organic farmers in siwa nobody supported them.

\section{Conclusion and discussions:}

1. SEAP failed to achieve sustainable agriculture development in siwa due to matrouh governor and miss- leading specialists' recommendations. 
2. SCDEC as an only association in the Oasis failed to take over and manage the assets and activities left by SEAP and shut them all down.

3. The farmers couldn't cope with the organic agriculture process with no support within from tribes or Association.

4. Since decentralization is the process of redistributing or dispersing functions, powers, people or things away from a central location or authority (free decionory.com, 2013), the results have shown the problem in the management system that allowed the governor of matrouh to be an obstacle. On the other hand decentralization should be the system that international organizations apply when they are offering or designing a plan or projects to help developing countries.

(fig.5) Graphical and decentralized system.

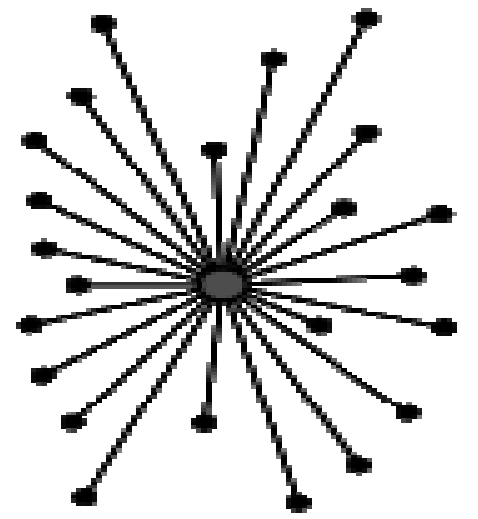

A.

comparison of centralized

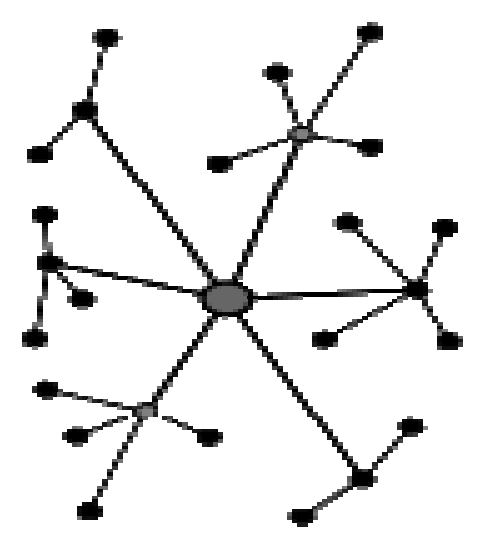

B

The word "centralization" came into use in France in 1794 as the post-French Revolution - French Directory leadership created a new government structure. The word "decentralization" came into usage in the 1820s (Vivien A. Schmidt, 2007)

Leopold Kohr, author of the 1957 book The Breakdown of Nations - known for its statement "Whenever something is wrong, something is too big"-was a major influence on E.F. 
Schumacher, author of the 1973 bestseller Small is Beautiful: Economics As If People Mattered (Dr. Leopold Kohr, 1994).

According to a 1999 United Nations Development Programme report:

"A large number of developing and transitional countries have embarked on some form of decentralization programs. This trend is coupled with a growing interest in the role of civil society and the private sector as partners to governments in seeking new ways of service delivery...Decentralization of governance and the strengthening of local governing capacity is in part also a function of broader societal trends. These include, for example, the growing distrust of government generally, the spectacular demise of some of the most centralized regimes in the world (especially the Soviet Union) and the emerging separatist demands that seem to routinely pop up in one or another part of the world. The movement toward local accountability and greater control over one's destiny is, however, not solely the result of the negative attitude towards central government. Rather, these developments, as we have already noted, are principally being driven by a strong desire for greater participation of citizens and private sector organizations in governance ("Decentralization: A Sampling of Definitions", 1999, )

So I guess we are not trying to approach a new idea or a new system of work. This is weird really why international organizations don't apply this system in order to apply the needed projects according to the people needs especially in Egypt.

On the other hand the decentralization system is not working in Egypt in a good way because such projects usually are applied and approved according to certain agreements done between Egypt and other countries under the umbrella of UNDP and in the end it is just waste of money.

5. Community participation could be the first step of solving the centralization problem through community development associations, and NGO, S.

The people should feel the power of social participation and the effect of their enrollment in decision making. It is unbelievable 
that a community Like Siwa with ten trips only works through one organization, another youth organizations should take place to gain the trust of international organizations.

\section{Recommendations:}

1. Egyptian government should start a survey in such locations to build a check list for the most important project needed by local people, so that the interested international organizations can choose from them easily.

2. Since there is a signed agreement it's important that the governor should not be an obstacle for such projects, laws should be updated.

3. Siwa need badly another new association with youth educated people in order to regain the trust of international organizations again.

\section{REFERENCES}

Barakat, Mazen, Siwa community Development and Environmental Conservation and dates. Export group: a revolution in the lost oasis, advanced special course on sustainable agriculture course, Mediterranean agronomic institute of Bari, 2011.

FAO/WFP, Socio economic and gender analysis (SEAGA) for emergency and rehabilitation programs,2005.bari university

Jules N Pretty, Agriculture sustainability: concepts, principles and evidence, 2008.bari university

Jules N Pretty, Regenerating agriculture, polices and practice for sustainability and self-reliance, 2006.

William Crichely, working with farmers' innovators, a practical guide, center of international cooperation, Veriji University, Amsterdam, 2007.

Definition of decentralization, The Free Dictionary.com, accessed February 4, 2013..

Vivien A. Schmidt, Democratizing France: The Political and Administrative History of Decentralization, Cambridge University Press, 2007

Dr. Leopold Kohr, 84; Backed Smaller States, New York Times obituary, February 28, 1994.

“Decentralization: A Sampling of Definitions", 1999, 


\title{
إستدامة مشاريع برنامج الأمم المتحدة الإنمائى في مصر \\ دراسة حالة في واحة سيوة الامن الحئ

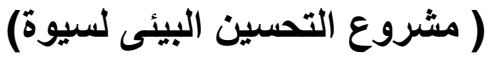

\author{
مازن محمد محمود بركات \\ قسم علم الاجتماع الريفي - كلية الزراعة ـ جامعة عين شمس مدر - مصر
}

المستخلص

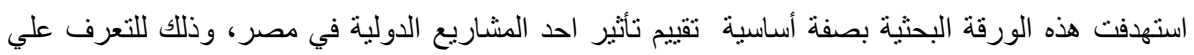

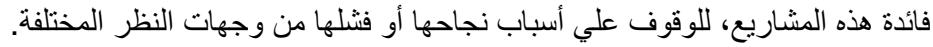

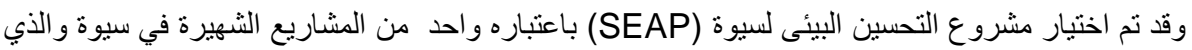

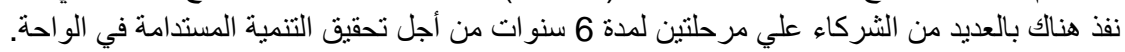

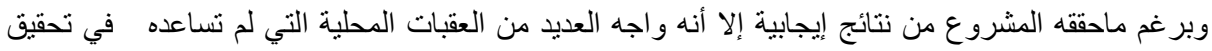

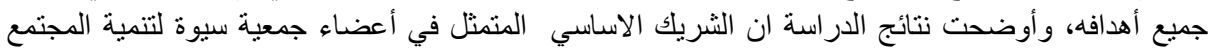

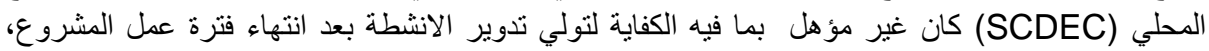

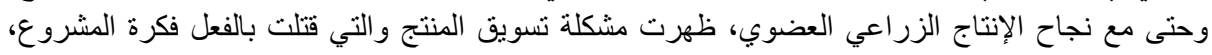

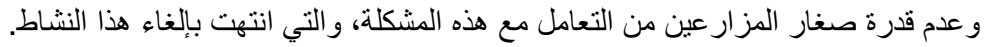

لقد أوضحت النتائج جليا ان مشكلة مركزية الادارة تعيق تحقيق التتمية في المناطق المختلفة بصفة رئيسية،

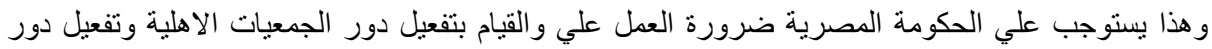

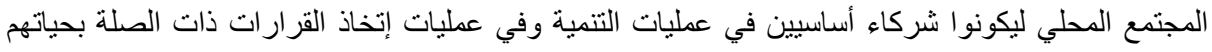

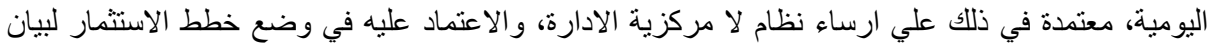

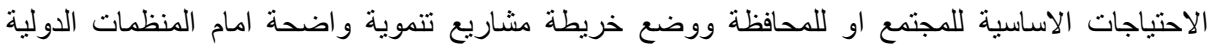

للاختيار من بينها. 